\title{
An Isomaltotriose-producing Dextranase from Flavobacterium sp. M-73: Purification and Properties
}

\author{
Mikihiko Kobayashi, Shiro TaKagi, Masao Shiota, \\ Yasushi Mitsuishi and Kazuo Matsuda
}

\author{
Department of Agricultural Chemistry, \\ Faculty of Agriculture, Tohoku University, \\ Sendai, Miyagi 980, Japan
}

Received May 9, 1983

\begin{abstract}
An isomaltotriose-producing dextranase II, detected in the culture supernatant of Flavobacterium sp. M-73, was purified to an electrophoretically pure state. Successive chromatography on hydrophobic columns of Amberlite CG-50 and aminooctyl-Sepharose was very effective as the first step of purification. Further purification of the enzyme was performed by affinity column chromatography on isomaltotriose-Sepharose and preparative polyacrylamide gel electrophoresis.

The purified enzyme was shown to be a monomer and had a molecular weight of 114,000 . Dextranase II was most active at $\mathrm{pH} 7.0$ and $35^{\circ} \mathrm{C}$. It was stable at $4^{\circ} \mathrm{C}$ for $24 \mathrm{hr}$ over a pH range of $6.5 \sim 12.0$ and up to $35^{\circ} \mathrm{C}$ on heating for $10 \mathrm{~min}$. This enzyme had a strict specificity for consecutive $\alpha-1,6$-glucosidic linkages and readily hydrolyzed clinical dextran and Sephadex gels. The degree of hydrolysis of clinical dextran was $31 \%$ expressed as apparent conversion into D-glucose. The amount of isomaltotriose in the hydrolyzate was determined to be $63 \%$.
\end{abstract}

In a previous paper, ${ }^{1)}$ we reported that two different types of dextranase, tentatively named dextranases I and II, were produced by a strain (M-73) belonging to a Flavobacterium species. The former enzyme (dextranase I) was purified to a satisfactorily pure state ${ }^{2)}$ and was characterized as a dextran $\alpha-1,2$ debranching enzyme (the systematic name: dextran 2-glucohydrolase) ${ }^{3)}$ The latter enzyme (dextranase II) was shown to produce mainly isomaltotriose from various dextrans, ${ }^{1)}$ but this enzyme was not examined further. The present paper describes the purification of and some properties of dextranase II.

\section{MATERIALS AND METHODS}

Materials. Clinical dextran (molecular weight, $75,000 \pm 25,000)$ was provided by Meito Sangyo Co., Japan. This dextran contains $95 \% \alpha$-1,6-glucosidic linkages. Aminooctyl-Sepharose 4B was prepared by the method of Shaltiel and Er-El. ${ }^{4}$

Microorganism and culture. The strain used in this study
(Flavobacterium sp. M-73) was the same as the one used in our previous study. ${ }^{1)}$ The culture medium was the same as described in a previous paper, ${ }^{1)}$ except that clinical dextran $(0.5 \%)$ was used instead of B-1299 soluble dextran $(0.3 \%)$. A stock culture of strain M-73 was inoculated into $10 \mathrm{ml}$ of the culture medium and incubated for $48 \mathrm{hr}$ at $30^{\circ} \mathrm{C}$ with shaking. The preculture was then transferred to 1 liter of the medium in 3 liter flasks and cultivated for $48 \mathrm{hr}$ at $30^{\circ} \mathrm{C}$ on a reciprocating shaker.

Assay system for dextranase II. The standard assay system consisted of $0.5 \mathrm{ml}$ of $0.5 \%$ clinical dextran solution in $50 \mathrm{~mm}$ phosphate buffer $(\mathrm{pH} 7.0)$ and $0.5 \mathrm{ml}$ of suitably diluted enzyme solution. The mixture was incubated for $10 \mathrm{~min}$ at $30^{\circ} \mathrm{C}$. The reaction was terminated by the addition of $1.0 \mathrm{ml}$ of alkaline copper reagent, and the reaction mixture was assayed for reducing sugar by the Nelson-Somogyi method. ${ }^{5,6)}$ One unit of dextranase II was defined as the amount of enzyme that catalyzed the liberation of reducing sugar equivalent to $1.0 \mu \mathrm{mol}$ of $\mathrm{D}-$ glucose per min under the standard conditions.

Polyacrylamide gel electrophoresis. Analytical gel electrophoresis was carried out according to the method of Davis $^{7)}$ with an acrylamide concentration of $7.5 \%$. The electrophoresis was continued for $2 \mathrm{hr}$ at $2 \mathrm{~mA}$ per column at $4{ }^{\circ} \mathrm{C}$. Preparative gel electrophoresis was carried out with 
$5 \%$ gel. Electrophoresis in the presence of sodium dodecyl sulfate (SDS) was carried out according to the method of Weber and Osborn ${ }^{8}$ for $6 \mathrm{hr}$ at $2 \mathrm{~mA}$ per column at room temperature. Protein was stained with Coomassie brilliant blue. Gel isoelectric focusing was performed according to the procedure described by Righetti and Drysdale ${ }^{9)}$ by a $\mathrm{pH}$ gradient with Ampholine ( $\mathrm{pH} 3.0 \sim 7.0$ ).

Analytical methods. Protein was determined by the method of Lowry et al. ${ }^{10)}$ or by absorbance at $280 \mathrm{~nm}$. Total carbohydrate was determined by the phenol-sulfuric acid method $^{11)}$ and represented as D-glucose.

Paper chromatography. Ascending paper chromatography was performed on Toyo No. 50 filter paper at room temperature with $70 \%$ aqueous 1-propanol (v/v). Spots were detected by the alkaline silver nitrate dipprocedure. $^{12)}$

Preparation of isomaltotriose-Sepharose $4 \mathrm{~B}$. Isomaltotriose-Sepharose 4B gel was prepared according to the method of Jeffrey et al. ${ }^{13)}$ Isomaltotetraose was coupled with ethylenediamine at $30^{\circ} \mathrm{C}$ for $48 \mathrm{hr}$ and reduced with $\mathrm{NaBH}_{4}$. The unreacted ethylenediamine was removed by gel filtration on a Bio-Gel P-2 column and the resulting isomaltotriose-aminoethane derivative was then coupled with $\mathrm{CNBr}$-activated Sepharose $4 \mathrm{~B}$ at $25^{\circ} \mathrm{C}$ for $16 \mathrm{hr}$.

\section{RESULTS}

\section{Production and purification of dextranase II}

The course of the production of dextranase
II was similar to that of the dextran $\alpha-1,2$ debranching enzyme (dextranase I). ${ }^{2)}$ The activity of extracellular dextranase II reached a maximum about $36 \mathrm{hr}$ after inoculation.

The culture broth ( 7 liters) was centrifuged at $10,000 \times g$ for $20 \mathrm{~min}$. The supernatant was subjected to the following purification steps. All the purification steps were carried out at $4^{\circ} \mathrm{C}$.

Step 1. Amberlite CG-50 column chromatography. The supernatant was adjusted to $\mathrm{pH} 4.2$ with $0.5 \mathrm{~m}$ acetate buffer $(\mathrm{pH} 4.0)$ and applied to an Amberlite CG-50 column ${ }^{14)}(7 \times 35.5 \mathrm{~cm})$ previously equilibrated with the same buffer. The column was washed with $0.5 \mathrm{~m}$ acetate buffer ( $\mathrm{pH} 4.0$ ) and then eluted with $0.5 \mathrm{M}$ acetate buffer ( $\mathrm{pH}$ 5.5). Fractions, 400 to $600 \mathrm{ml}$ each, were collected and the fractions containing dextranase II activity were pooled and dialyzed against $10 \mathrm{~mm}$ Tris- $\mathrm{HCl}$ buffer (pH 8.0). By this step, the specific activity of the enzyme was increased 7.7-fold over the culture supernatant (Fig. 1).

Step 2. Aminooctyl-Sepharose 4B column chromatography. The dialyzed solution from Step 1 was applied to an aminooctylSepharose 4B column $(2.5 \times 12 \mathrm{~cm})$ previously equilibrated with $10 \mathrm{~mm}$ Tris- $\mathrm{HCl}$ buffer $(\mathrm{pH}$

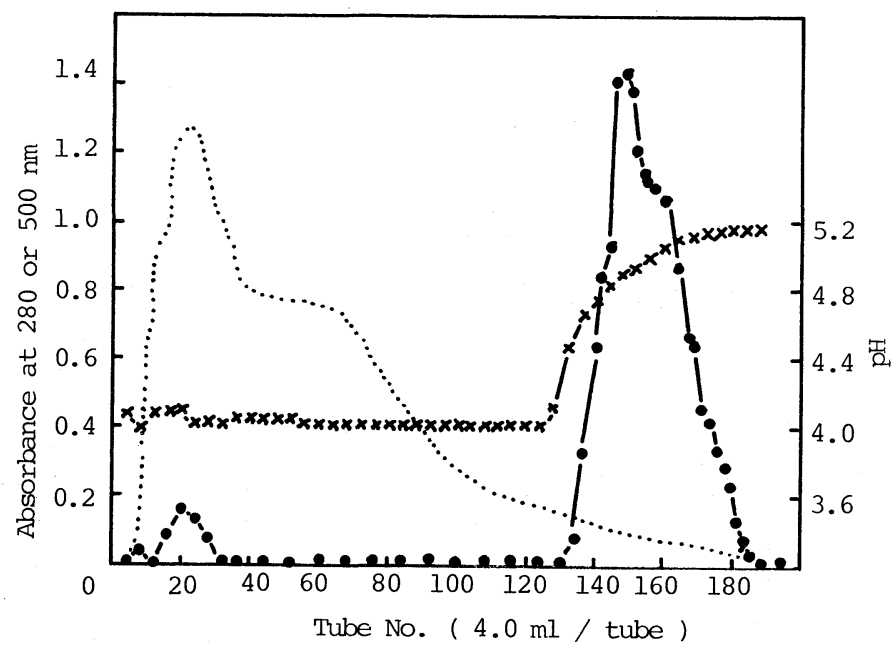

FIG. 1. Representative Elution Pattern of Dextranase II from the Amberlite CG-50 Column.

The culture supernatant $(12$ units $/ 250 \mathrm{ml})$ from Flavobacterium sp. M-73 was applied to the column $(2.5 \times$ $10 \mathrm{~cm})$ and $4 \mathrm{ml}$ fractions were collected. For preparative purposes, a larger column $(7 \times 35.5 \mathrm{~cm})$ was used, as described in the text. Symbols: $\bigcirc$, enzyme activity (absorbance at $500 \mathrm{~nm}$ ); $\times, \mathrm{pH}$ of acetate buffer; -- absorbance at $280 \mathrm{~nm}$. 


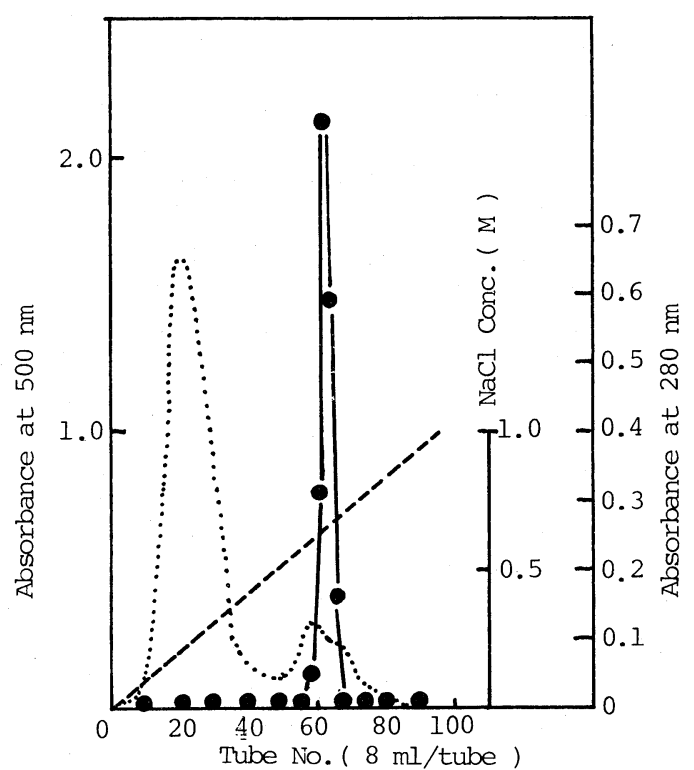

FIG. 2. Elution Pattern of Dextranase II from the Aminooctyl-Sepharose 4B Column.

Symbols: enzyme activity; ------, absorbance at $280 \mathrm{~nm}$; $\mathrm{NaCl}$ concentration.

8.0). The column was eluted with a linear gradient of $0 \sim 1.0 \mathrm{M} \mathrm{NaCl}$ in the same buffer (Fig. 2). The fractions with the enzyme activity were pooled and dialyzed against deionized water.

Step 3. Isomaltotriose-Sepharose $4 B$ affinity column chromatography. The dialyzed solution from Step 2 was adjusted to $\mathrm{pH} 11.5$ with $50 \mathrm{~mm}$ borate buffer $(\mathrm{pH} \mathrm{11.5)}$ and allowed to stand at $4^{\circ} \mathrm{C}$ for $24 \mathrm{hr}$. By this treatment, the concomitant $\alpha-1,2$ debranching enzyme activity was completely inactivated. The enzyme solution thus treated was dialyzed against $10 \mathrm{~mm}$ Tris- $\mathrm{HCl}$ buffer ( $\mathrm{pH} 8.0$ ) and the dialyzed solution was applied to an affinity column $(1.4 \times 6.2 \mathrm{~cm})$ of isomaltotrioseSepharose $4 \mathrm{~B}$ previously equilibrated with the same buffer containing $0.1 \mathrm{M} \mathrm{NaCl}$. The column was washed with the same buffer used for equilibration and then eluted with Tris- $\mathrm{HCl}$ buffer ( $\mathrm{pH} 8.0$ ) containing $0.1 \mathrm{M} \mathrm{NaCl}$ and $0.1 \%$ clinical dextran (Fig. 3). Although a part of dextranase II activity was eluted at the breakthrough fraction, most of the enzyme

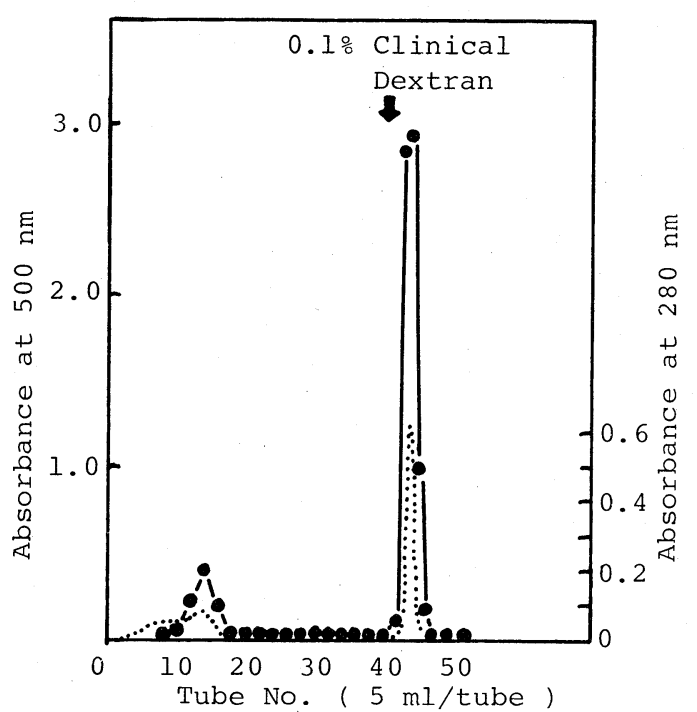

FIG. 3. Elution Pattern of Dextranase II from the Isomaltotriose-Sepharose 4B Column.

Symbols: - enzyme activity; ------, absorbance at $280 \mathrm{~nm}$. The arrow indicates elution with $0.1 \%$ clinical dextran in $10 \mathrm{~mm}$ Tris- $\mathrm{HCl}$ buffer $(\mathrm{pH} 8.0$ ) containing $0.1 \mathrm{M} \mathrm{NaCl}$.

activity was biospecifically adsorbed to the affinity column through the ligand of isomaltotriose and was eluted with $0.1 \%$ clinical dextran solution.

Step 4. DEAE-cellulose column chromatography. The effluents with the enzyme activity were pooled and then applied to a DEAEcellulose column $(1.4 \times 6.0 \mathrm{~cm})$ previously equilibrated with $10 \mathrm{~mm}$ Tris- $\mathrm{HCl}$ buffer $(\mathrm{pH}$ 8.0). After washing with the same buffer, the column was eluted with a gradient of $0 \sim 1.0 \mathrm{M}$ $\mathrm{NaCl}$ in the same buffer. The fractions with the enzyme activity were pooled and concentrated with a collodion bag (Sartorius membrane filter, collodion bag 12). By this procedure, the enzyme activity and clinical dextran were completely separated from each other.

Step 5. Preparative polyacrylamide gel electrophoresis. The concentrated enzyme solution from Step 4 was dialyzed against $10 \mathrm{~mm}$ Tris$\mathrm{HCl}$ buffer ( $\mathrm{pH} \mathrm{8.0)}$ and the dialyzed solution was subjected to preparative gel electrophoresis. The sliced gel sections $(2 \mathrm{~mm})$ were extracted with $0.5 \mathrm{ml}$ of $10 \mathrm{~mm}$ Tris- $\mathrm{HCl}$ buffer ( $\mathrm{pH} 8.0$ ) for $24 \mathrm{hr}$ at $4^{\circ} \mathrm{C}$ and the enzyme 


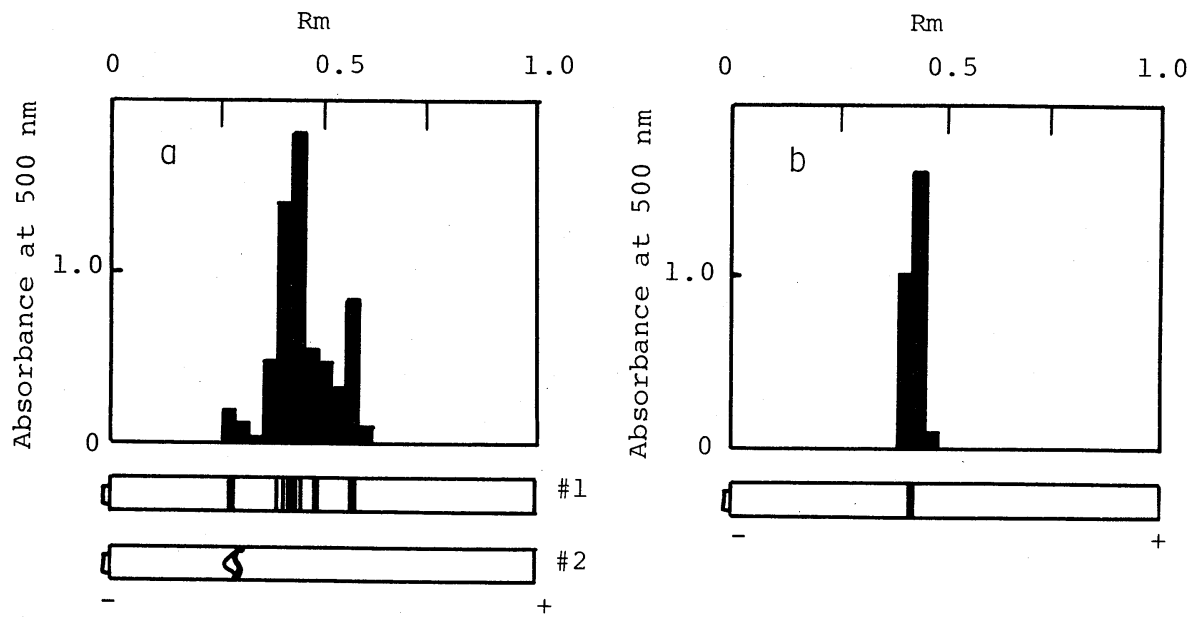

FIG. 4. Analytical Gel Electrophoresis of Dextranase II.

a: Enzyme activity (top) and protein bands (middle: Lane \#1) of the DEAE-cellulose fraction. The same fraction was analyzed by an acrylamide gel containing $0.1 \%$ clinical dextran (bottom: Lane \#2).

b: Enzyme activity (top) and protein band (bottom) of the purified enzyme after the preparative gel electrophoresis step.

Table I. Purification of Dextranase II from Flavobacterium sp. M-73

\begin{tabular}{|c|c|c|c|c|c|}
\hline Steps & $\begin{array}{l}\text { Protein } \\
\text { (mg) }\end{array}$ & $\begin{array}{l}\text { Activity } \\
\text { (units) }\end{array}$ & $\begin{array}{l}\text { S.A. }{ }^{a} \\
(\mathrm{u} / \mathrm{mg})\end{array}$ & $\begin{array}{l}\text { Purification } \\
\text { (fold) }\end{array}$ & $\begin{array}{c}\text { Recovery } \\
(\%)\end{array}$ \\
\hline Broth sup & 1430.0 & 336 & 0.234 & 1 & 100.0 \\
\hline Broth sup (pH 4.2) & - & 161 & - & - & 47.9 \\
\hline Amberlite CG-50 & 65.8 & 119 & 1.81 & 7.7 & 35.4 \\
\hline Aminooctyl-Sepharose & 3.34 & 67.2 & 20.1 & 85.9 & 20.0 \\
\hline $\mathrm{pH}$ treatment & - & 65.2 & - & - & 19.4 \\
\hline $\mathrm{IM}_{3}-$ Sepharose $^{b}$ & - & 50.4 & - & - & 15.0 \\
\hline DEAE-cellulose & 1.13 & 38.5 & 34.0 & 145.3 & 11.5 \\
\hline Preparative PAGE ${ }^{c}$ & 0.28 & 10.1 & 36.3 & 155.1 & 3.0 \\
\hline
\end{tabular}

a Specific activity (units/mg protein).

$b$ Isomaltotriose-Sepharose 4B.

c Polyacrylamide gel electrophoresis.

activity was assayed for each section. As the gel electrophoresis showed at least seven protein bands with overlapping enzyme activities (Fig. 4a), the main component with the highest activity ( $\mathrm{Rm} 0.42)$ was extracted from the gel. The extracts were pooled and concentrated as above.

The purification steps of dextranase II are summarized in Table I. The finally purified dextranase II had a specific activity of 36 units per $\mathrm{mg}$ protein and was obtained in a final yield of $3 \%$. The enzyme was purified 150 -fold over the culture supernatant.

Purity and molecular weight of dextranase II

As shown in Fig. 4b, the final enzyme preparation gave a single protein band and the dextranase activity coincided well with the position of the protein band on the gel. The molecular weight of this enzyme was estimated to be 116,000 by SDS-polyacrylamide gel electrophoresis (Fig. 5a) and 111,000 by gel filtration on Sepharose CL-6B column (Fig. 5b). According to the method of Hedrick-Smith, ${ }^{15}$ ) 

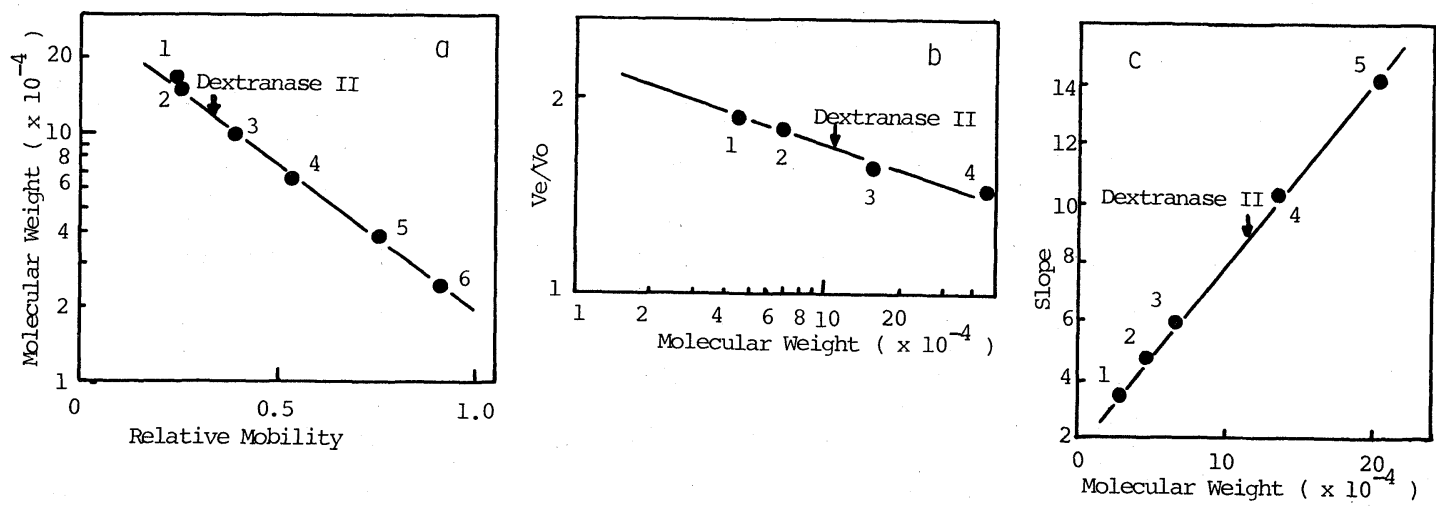

FIG. 5. Determination of Molecular Weight of Dextranase II by SDS-Gel Electrophoresis (a), Gel Filtration on Sepharose CL-6B (b) and the Hedrick-Smith Method (c).

The molecular weight of standard proteins used in (a): 1, RNA polymerase $\beta^{\prime}, 165,000 ; 2$, RNA polymerase $\beta$, 155,$000 ; 3$, rabbit muscle glycogen phosphorylase $b, 98,400 ; 4$, albumin (bovine), 67,000; 5, RNA polymerase $\alpha, 39,000 ; 6$, chymotrypsinogen, 25,000. (b): 1, ovalbumin, 45,000;2, albumin (bovine), 67,000; 3, aldolase, 158,$000 ; 4$, ferritin, 450,000. (c): 1 , chymotrypsinogen, 25,000;2, ovalbumin, 45,000; 3, albumin (bovine) monomer, 67,000; 4, dimer, 134,000; 5, trimer, 201,000.

the molecular weight of the enzyme was estimated to be 114,000 by electrophoretic analysis (Fig. 5c). Therefore, dextranase II was shown to have no oligomeric forms and the molecular weight was approximately 114,000 by three different methods. The isoelectric point of the enzyme was at $\mathrm{pH} 4.1$ (data not shown).

\section{Multiple forms of dextranase II}

Electrophoretic analysis indicated that seven protein bands were detected from the enzyme preparation (Step 3) after the affinity column chromatography with isomaltotrioseSepharose (Fig. 4a). The multiplicity of dextranase II was examined by gel electrophoresis with various gel concentrations. As shown in Fig. 6, seven proteins (A to G) were detected by staining with Coomassie blue. Molecular weights of these proteins were in the range of 131,000 (band A) to 97,000 (band G). Protein bands of $\mathrm{C}, \mathrm{D}, \mathrm{E}$ and $\mathrm{F}$ gave parallel lines (slope 8.2) indicating that these proteins differ in net charge but have almost the same molecular size $(114,000)$ as defined by HedrickSmith. ${ }^{15)}$ When this preparation was subjected to affinity-gel electrophoresis with $7.5 \%$ gel containing $0.1 \%$ clinical dextran, a single pro-

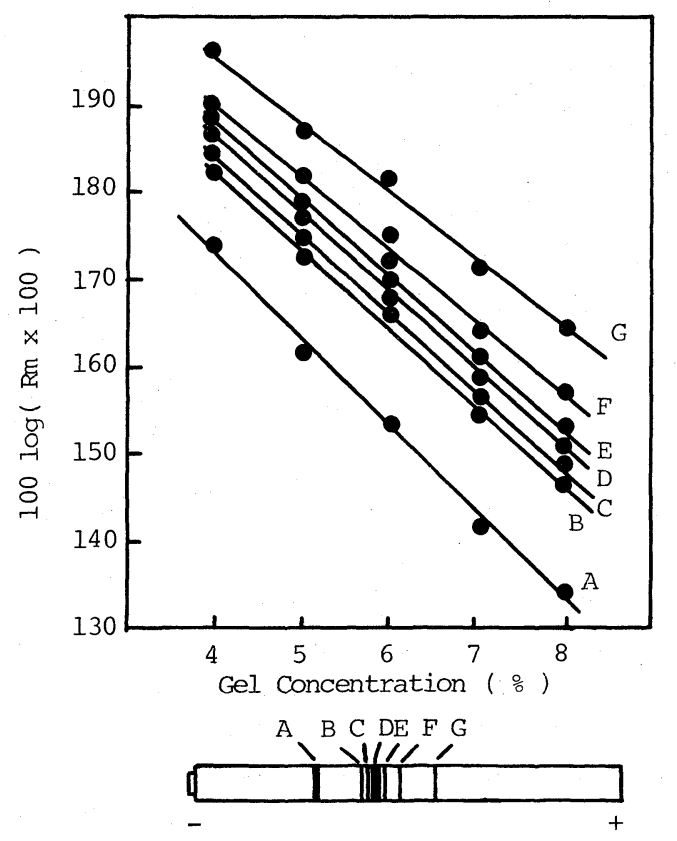

FIG. 6. Effect of Gel Concentration on the Mobility of Dextranase II.

Symbols $A$ to $\mathrm{G}$ correspond to the protein bands shown in the bottom gel. The average value of the slopes was $8.7 \pm 1.0$.

tein band ( $\mathrm{Rm} \mathrm{0.32)}$ was detected (Fig. 4a lane \#2). These results suggest that all of these proteins are related with each other in mo- 

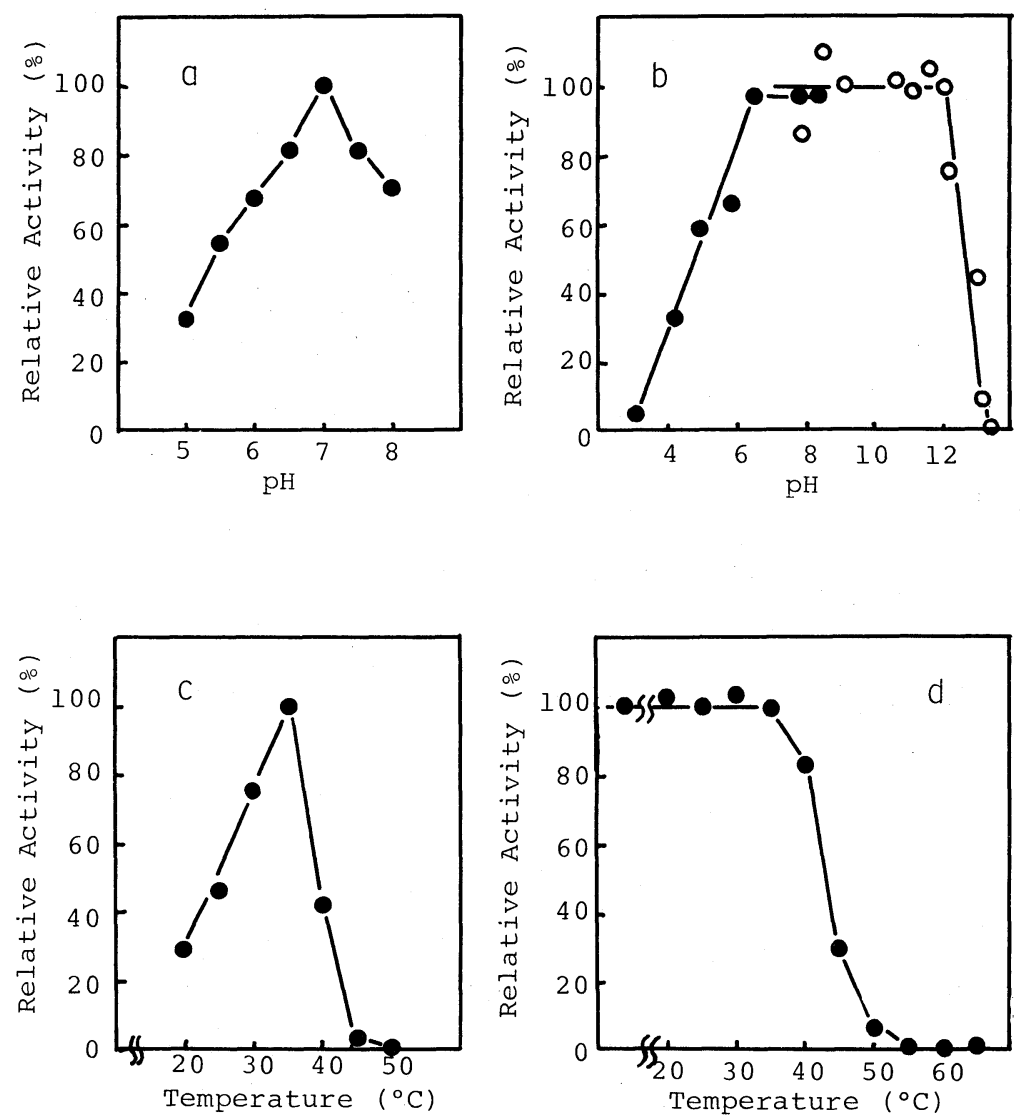

FIG. 7. Effects of $\mathrm{pH}$ and Temperature on Dextranase II.

(a) Optimal $\mathrm{pH}$. The enzyme activity was determined with $0.1 \mathrm{M}$ McIlvaine buffer. (b) $\mathrm{pH}$ stability. McIlvaine buffer; $\bigcirc, 50 \mathrm{~mm}$ borate buffer. (c) Optimal temperature. (d) Thermal stability.

lecular size and affinity for the dextran.

\section{General properties of dextranase II}

The following experiments were carried out with the finally purified preparation (Step 5). Dextranase II was most active at pH 7.0 (Fig. 7a) and was stable in the range of $\mathrm{pH} 6.5$ to 12.0 at $4^{\circ} \mathrm{C}$ for $24 \mathrm{hr}$ (Fig. 7b). The temperature optimum for the enzyme activity was at $35^{\circ} \mathrm{C}$ (Fig. 7c) and the purified enzyme was stable at temperatures below $35^{\circ} \mathrm{C}$ for $10 \mathrm{~min}$ (Fig. 7d). Table II shows the effects of metal ions and chemicals on the enzyme activity. The enzyme was strongly inhibited by $\mathrm{Cu}^{2+}, \mathrm{Hg}^{2+}$, and $\mathrm{Zn}^{2+}(2 \mathrm{mM})$, whereas $\mathrm{Mg}^{2+}, \mathrm{Mn}^{2+}$, and $\mathrm{Ca}^{2+}$ caused 54 to $22 \%$ of activation. Among the chemicals tested, EDTA showed $33 \%$ in-
Table II. EfFects of Metal Ions and Chemicals ON THE ACTIVITY of Dextranase II

Final concentration of metal ions (used in the chloride form) and chemical reagents was $2.0 \mathrm{~mm}$, except for $p$ chloromercuribenzoate $^{a}(0.2 \mathrm{~mm})$.

\begin{tabular}{crlc}
\hline Compound & $\begin{array}{c}\text { Relative } \\
\text { activity } \\
(\%)\end{array}$ & Compound & $\begin{array}{c}\text { Relative } \\
\text { activity } \\
(\%)\end{array}$ \\
\hline None & 100 & $\mathrm{Ca}^{2+}$ & 122 \\
$\mathrm{Zn}^{2+}$ & 18 & $\mathrm{Al}^{3+}$ & 97 \\
$\mathrm{Mn}^{2+}$ & 132 & $\mathrm{CH}_{2} \mathrm{ICOOH}$ & 96 \\
$\mathrm{Mg}^{2+}$ & 154 & $p \mathrm{CMB}^{a}$ & 89 \\
$\mathrm{Cu}^{2+}$ & 0 & EDTA & 67 \\
$\mathrm{Fe}^{3+}$ & 66 & $\delta$-Glucono- & 100 \\
$\mathrm{Co}^{2+}$ & 88 & lactone & \\
$\mathrm{Hg}^{2+}$ & 3 & Sorbitol & 95 \\
& & NaF & 97
\end{tabular}


Table III. Substrate Specificity of DeXtranase II

Dextranase II (0.02 units) was mixed with $0.1 \%$ of each

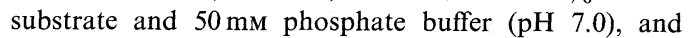
incubated for $24 \mathrm{hr}$ at $30^{\circ} \mathrm{C}$.

\begin{tabular}{llc}
\hline \multicolumn{1}{c}{ Substrate } & $\begin{array}{c}\text { Major } \\
\text { linkage }\end{array}$ & $\begin{array}{c}\text { Relative } \\
\text { activity } \\
(\%)\end{array}$ \\
\hline Clinical dextran & $\alpha-1,6$ & 100 \\
Glycogen & $\alpha-1,4$ & 0 \\
Soluble starch & $\alpha-1,4$ & 0 \\
Pachyman & $\beta-1,3$ & 0 \\
$\beta$-1,6-Glucan & $\beta-1,6$ & 0 \\
CM-Sephadex & $\alpha-1,6$ & 0 \\
DEAE-Sephadex & $\alpha-1,6$ & 0 \\
Pullulan & $\alpha-1,4, \alpha-1,6$ & 0 \\
Sephadex G-15 & $\alpha-1,6$ & 10.2 \\
Sephadex G-75 & $\alpha-1,6$ & 52.5 \\
Sephadex G-200 & $\alpha-1,6$ & 69.2 \\
\hline
\end{tabular}

hibition while D-glucono-1,5-lactone had no significant effect on the activity. Activation by $\mathrm{Mg}^{2+}$ was completely repressed by the addition of $5 \mathrm{~mm}$ EDTA (data not shown).

\section{Substrate specificity of dextranase II}

Several glucans containing various types of glucosidic linkages were digested with dextranase II, and the degree of hydrolysis of each substrate was determined. The results are summarized in Table III. Glucans without $\alpha-1,6-$ linkages were not hydrolyzed by this enzyme at all. Moreover, dextran derivatives such as DEAE-Sephadex and CM-Sephadex were not susceptible to dextranase II although crosslinked Sephadex gels were degraded to a large extent. Paper chromatography of the hydrolyzate of the clinical dextran with dextranase II showed that isomaltotriose was the major product (Fig. 8). Besides isomaltotriose, isomaltose, isomaltotetraose, and an unknown sugar were detected after $8 \mathrm{hr}$ digestion. Based on the structure of the substrate clinical dextran, it is suggested that the unknown sugar may have one $\alpha-1,3$ branched glucose on the linear isomaltotriose structure. The hydrolysis of the clinical dextran with dextranase II reached a maximum after $10 \mathrm{hr}$ incubation and the degree of hydrolysis was $31.0 \%$ expressed as ap-

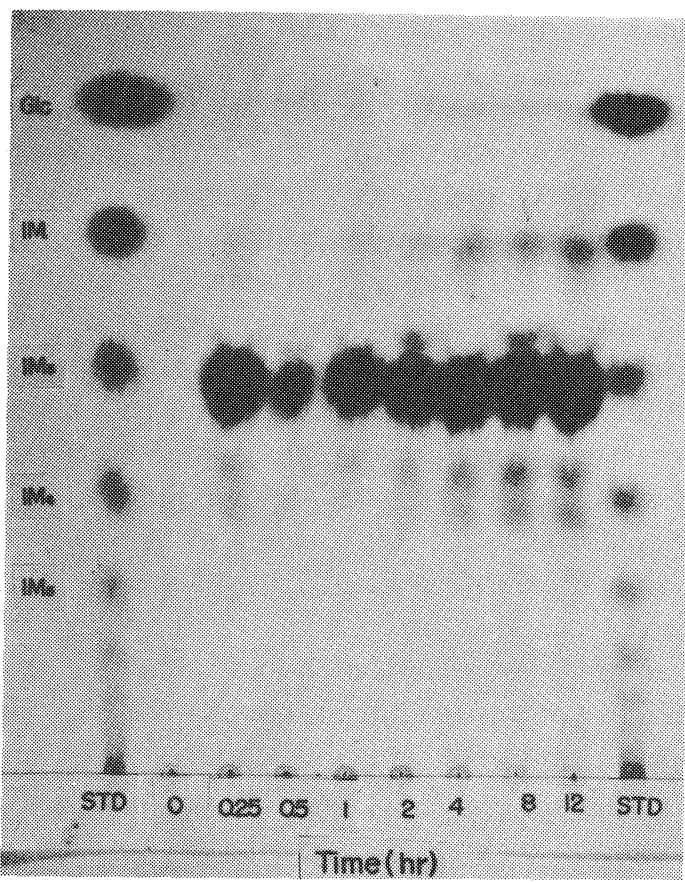

FIG. 8. Paper Chromatogram of the Digest of Clinical Dextran with Dextranase II.

STD Glc, D-glucose; $\mathrm{IM}_{2}$, isomaltose; $\mathrm{IM}_{3}$, isomaltotriose; $\mathrm{IM}_{4}$, isomaltotetraose.

TABle IV. Oligosaccharide Composition IN THE Hydrolyzate of Clinical DeXtran with DeXtranase II

\begin{tabular}{lcc}
\hline Sugar produced & $\begin{array}{c}\text { Relative (\%) } \\
\text { as D-glucose }\end{array}$ & $\begin{array}{c}\text { Relative } \\
\text { molar ratio }\end{array}$ \\
\hline Glucose & 0.9 & 1 \\
Isomaltose & 0.4 & 0.2 \\
Isomaltotriose & 63.4 & 25.2 \\
Branched tetraose & 4.6 & 3.4 \\
Isomaltotetraose & 7.0 & - \\
Higher oligomer & 23.7 & - \\
\hline Total & 100.0 & - \\
\hline
\end{tabular}

parent conversion into D-glucose. The sugar component in the digest was analyzed by paper chromatography and the amount of isomaltotriose in the hydrolyzate was determined to be $63.4 \%$ (Table IV). The relative molar ratio of D-glucose, isomaltose, isomaltotriose, and tetrasaccharide mixture (total of branchedsaccharide and isomaltotetraose) was calculated to be $1: 0.2: 25.2: 3.4$ (Table IV). 


\section{DISCUSSION}

An attempt was made to purify dextranase II by affinity chromatography on Sephadex gel, but purification by this method was not successful. The susceptibility of Sephadex gel to dextranase II caused us to search for another affinity gel stable to this enzyme. For this purpose, we prepared three different types of affinity gels and tested their specificity for this enzyme. These gels are: IsomaltotrioseSepharose 4B, prepared by coupling of $\mathrm{CN}$ Sepharose $4 B$ and isomaltotetraose ${ }^{13,16)}$; Isomaltotriose-hexamethylene-Sepharose 4B, prepared by carbodiimide coupling of aminohexyl-Sepharose 4B and isomaltotrionic $\operatorname{acid}^{17)}$; and isomaltotriose-Sepharose 6B, prepared by treatment of Sepharose $6 \mathrm{~B}$ and butanediol-diglycidylether (epoxy reagent) ${ }^{18)}$ followed by coupling with isomaltotriose. Of these gels, the isomaltotriose-Sepharose 4B gel was most effective for the purification of dextranase II.

The final products from non-branched dextrans by dextranase are, in most cases, isomaltose and/or glucose. ${ }^{19,20)}$ Only a few dextranases are reported to produce isomaltotriose as the major product. Sugiura et al. $^{21)}$ reported that an exo-dextranase from Brevibacterium fuscum produced isomaltotriose as the sole hydrolysis product. The degree of hydrolysis of a virtually non-branched dextran with this enzyme was $14 \%$ expressed as apparent conversion into D-glucose. The degree of hydrolysis of clinical dextran with our enzyme was $31 \%$ expressed as D-glucose and the content of isomaltotriose in the hydrolyzate was $63.4 \%$. These results suggest that the Flavobacterium dextranase, dextranase II, yields isomaltotriose more effectively than the exo-dextranase from Brevibacterium. The action pattern and substrate specificity of the dextranase II will be reported in detail in our subsequent paper.

Another isomaltotriose-producing enzyme was reported by Pulkownik and Walker. ${ }^{22)}$ This enzyme was an extracellular endodextranase produced by Streptococcus mutans
K1-R. The hydrolysis of virtually nonbranched dextran with this enzyme was almost complete, but the soluble glucan of S. mutans was hydrolyzed only to a limited extent. The activity of this enzyme seems to be comparable to that of our enzyme, although general properties of these two enzymes are somewhat different from each other. Whereas the enzymes of Brevibacterium and Streptococcus are both extracellular enzymes, major part of the enzyme activity of dextranase II from Flavobacterium was retained in the cells as a cell-bound enzyme. Such association of the enzyme with the cells may be of great advantage in utilizing this enzyme as an immobilized preparation.

\section{REFERENCES}

1) M. Kobayashi, Y. Mitsuishi and K. Matsuda, Biochem. Biophys. Res. Commun., 80, 306 (1978).

2) Y. Mitsuishi, M. Kobayashi and K. Matsuda, Agric. Biol. Chem., 43, 2283 (1979).

3) Y. Mitsuishi, M. Kobayashi and K. Matsuda, Carbohydr. Res., 83, 303 (1980).

4) S. Shaltiel and Z. Er-El, Proc. Natl. Acad. Sci. U.S.A., 70, 778 (1973).

5) N. Nelson, J. Biol. Chem., 153, 375 (1944).

6) M. Somogyi, J. Biol. Chem., 160, 61 (1945).

7) B. J. Davis, Ann. N. Y. Acad. Sci., 121, 404 (1964).

8) K. Weber and M. Osborn, J. Biol. Chem., 244, 4406 (1969).

9) P. G. Righetti and J. W. Drysdale, J. Chromatogr., 98, 271 (1974).

10) O. H. Lowry, N. J. Rosebrough, A. L. Farr and R. J. Randall, J. Biol. Chem., 193, 265 (1951).

11) M. Dubois, K. A. Gilles, J. K. Hamilton, P. A. Rebers and F. Smith, Anal. Chem., 28, 350 (1956).

12) W. F. Trevelyan, D. P. Procter and J. S. Harrison, Nature, 166, 444 (1950).

13) A. M. Jeffrey, D. A. Zopf and V. Ginsburg, Biochem. Biophys. Res. Commun., 62, 608 (1975).

14) I. Sasaki, H. Goto, R. Yamamoto, H. Hasegawa, J. Yamashita and T. Horio, J. Biochem., 86, 1537 (1979).

15) J. L. Hedrick and A. J. Smith, Arch. Biochem. Biophys., 126, 155 (1968).

16) D. A. Zopf, D. F. Smith, Z. Drzeniek, C.-M. Tsai and V. Ginsburg, Methods Enzymol., 50, 171 (1978).

17) N. Weliky, H. H. Weetall, R. V. Gilden and D. H. Campbell, Immunochemistry, 1, 219 (1964).

18) J. Porath, R. Axén and S. Ernback, Nature, 215, 1491 (1967). 
19) J. J. Marshall, Adv. Carbohydr. Chem. Biochem., 30, 21) M. Sugiura, A. Ito and T. Yamaguchi, Biochim. 338 (1974). Biophys. Acta, 350, 61 (1974).

20) S. Minato, Nippon Nôgeikagaku Kaishi, 57, $155 \quad$ 22) A. Pulkownik and G. J. Walker, Carbohydr. Res., 54, (1983). 237 (1977). 